\title{
COMPREHENSIVENESS OF A STRATEGY EXECUTION MEASUREMENT SYSTEM
}

\begin{abstract}
The article describes the issue of strategy execution measurement taking into consideration two variables - the level of its comprehensiveness and the effectiveness of activities performed. The comprehensiveness was defined by means of three areas: the use of measurement tools, processes and regularity of the measurement work conducted. Whereas the effectiveness of strategy implementation was expressed through the level to which intended strategic objectives are achieved and income dynamics. The research sample included managers of 200 companies that have been operating for at least 5 years and are listed among the 500 largest Polish companies in the ranking of "Polityka" magazine and in the "Forbes Diamonds 2013" ranking. The study was conducted the PAPI (Paper and Pencil Interview) technique. The questions in the questionnaire were of nominal value (the respondents declared the existence of specific obstacles) and or ordinal variable nature (the respondents indicated the strength of their impact on a 5-point scale). In order to test the hypotheses, Pearson's correlation coefficient was calculated. The research has shown the existence of a positive correlation between these, indicating that the greatest role is played by appropriately designed measurement processes. Concurrently, it is important to take into consideration mutual interactions between the elements of the measurement system, in order to adopt a holistic perspective and design it using the comprehensive approach.
\end{abstract}

Keywords: strategy execution, measurement system, strategic goals, strategic management, control

\section{INTRODUCTION}

The literature review showed that there is a lack of a consistent definition of the measurement system, concerning also the strategy execution measurement system. Researchers present different statements regarding its components and measures used. This is, however, one of the key aspects of the strategy implementation process as it influences the opportunity for necessary correction and is a tool for diagnosing crucial elements determining the achievement of objectives. It is, thus a relevant and important research area, in particular due to the high percentage of implementation failure ${ }^{2}$ and low efficiency of existing systems for measurement of results achieved, as well as the low degree of usefulness and applicability of information acquired ${ }^{3}$. The key problem is the choice of proper measures from the wide variety of options available, the establishment of the regularity of

\footnotetext{
${ }^{1}$ Joanna Radomska, Strategic Management Department, Wrocław University of Economics, Komandorska 118/120, 53-345 Wrocław, tel. 713680209, e-mail: joanna.radomska@ue.wroc.pl.

${ }^{2}$ H. Sirkin, P. Keenan, A. Jackson, The hard side of change management, "Harvard Business Review" 83(10)/(2005), p. 109-118; L. Hrebiniak, Making Strategy Work. Leading effective execution and change, 2nd edition, Pearson Education, New Jersey, 2013.

${ }^{3}$ L. Maisel, Performance Measurement Practices: A Long Way from Strategic Management, "Balanced Scorecard Report" May - June/(2001).
} 
activities conducted and the design of the appropriate processes. This is connected with the character of the organisation and field in which it operates ${ }^{4}$.

The objective of this work is an examination of the relationships between a comprehensive strategy execution measurement system and the results of activities conducted. Also the organization size was considered.

\section{LITERATURE REVIEW AND HYPOTHESES}

A general definition of a measurement system describes it as a balanced and dynamic system supporting the process by which decisions (including those of a strategic nature) are taken, through the collection, compilation and analysis of information ${ }^{5}$. However, it is essential to ensure simultaneously organisational adaptation - each system should consider such variables as strategy being executed, objectives, structures, culture and technolo$\mathrm{gy}^{6}$. It can therefore be stated that this is an integral element of the strategic development process $^{7}$, and a lack of coherence between measurement system and strategy being executed may cause significant difficulties in achieving the results intended ${ }^{8}$.

A broader notion is the measurement of results from activity conducted, which is composed of procedures utilised to graduate measures reflecting best the degree of strategy execution at the organisation ${ }^{9}$. This integrates two functions - communication among all participants concerning setting and measuring the objectives as well as providing the information on results achieved, the course of processes and profitability of products or business entities ${ }^{10}$. This is thus information necessary for assessment of the relevance and content of the strategy devised ${ }^{11}$. Its main role, however, though not the only, is the consideration of implementation progress ${ }^{12}$ by integrating the financial, strategic and operational indicators ${ }^{13}$. As a result, it is a tool supporting the processes of planning, measurement and control of results achieved as well as ensuring the conformity of the work of particular departments with the strategy ${ }^{14}$. The outcome of a properly functioning strategy execution measurement system is the opportunity to define effectiveness as a measure of

${ }^{4}$ D. Medori, D. Steeple, A framework for auditing and enhancing performance measurement systems, "International Journal of Operations \& Production" 20(5)/(2000), p. 523.

${ }^{5}$ A. Neely, C. Adams, M. Kennerley, The Performance Prism: The Scorecard for Measuring and Managing Stakeholder Relationship, Prentice-Hall, London, 2002.

${ }^{6} \mathrm{R}$. Chenhall, Management control system design within its organizational context: findings from contingencybased research and directions for the future, "Accounting, Organizations and Society" 28/(2003), p. 127-68.

${ }^{7}$ G. Dangayach, S. Deshmukh, Manufacturing strategy literature review and some issues, "International Journal of Operations \& Production Management" 21(7)/(2001), p. 884-932.

${ }^{8}$ P. Garengo, S. Biazzo, U. Bititci, Performance measurement system in SMSs: a review for a research agenda, "International Journal of Management Reviews" 7(5)/(2005), p. 25-47.

${ }^{9}$ S. Gates, Aligning Strategic Performance Measures and Results, The Conference Board, New York, 1999, p. 4.

${ }^{10}$ C. Forza, F. Salvador, Assessing some distinctive dimensions of performance feedback information in high performing plants, "International Journal of Operations and Production Management" 20(3)/(2000), p. 359.

${ }^{11}$ C. Ittner, D. Larcker, T. Randall, Performance implications of strategic performance measurement in financial service firms, "Accounting, Organizations and Society" 28(7/8)/(2003), p. 734

${ }^{12}$ M. Franco-Santos, M. Kennerley, P. Micheli, V. Martinez, S. Mason, B. Marr, D. Gray, A. Neely, Towards a definition of a business performance measurement system, "International Journal of Operations \& Production Management", 27(8)/(2007), p. 795.

${ }^{13}$ S. Gates, Aligning Strategic Performance Measures and Results, The Conference Board, New York, 1999, p. 24.

${ }^{14}$ L. Maisel, Performance Measurement Practices Survey Results, AICPA, New York, 2001, p. 12. 
ability to achieve planned effects of activities undertaken and efficiency, as a measure of ability to execute set goals with certain limitations ${ }^{15}$. In the literature relating to the measurement and controlling system, a great deal of attention is devoted to ensuring the integration and coherence of these two variables with the strategy being executed ${ }^{16}$. As research results indicate, for many organisations the measurement of strategy implementation results is becoming almost an obsession, chiefly due to the need for proper allocation of available resources ${ }^{17}$.

The control and measurement of implementation progress are also a part of the risk management process. These are constituents of its proper course, although it is essential to ensure the completeness, precision, relevance and integrity of the entire process by which decisions are taken, including those of a strategic nature ${ }^{18}$. This demands cohesion and transparency of both strategic goals and the communication of the course of activities being executed as well as current and scrupulous reporting of the level of execution of key indicators. Crucial, therefore, is the synchronisation of strategy, the risk management system and operational activities ${ }^{19}$.

A system to measure the effectiveness of activities is useful in both the issue of the implementation of strategy and the methods for its modification ${ }^{20}$. These aspects are mutually bound and it is essential to ensure their integrity. This is proven by some research results indicating that as many as $80 \%$ of entities surveyed had introduced changes in their measurement system within the last three years as a result of the correction of the development concept ${ }^{21}$.

In the literature there is a lack of an explicit recommendation regarding the choice of measures best reflecting the progress of strategy implementation. On the one hand, it is implied that focusing too much on some indicators (such as EPS) does not bring the intended effects due to an excessive concentration on financial results without ensuring coherence with other aspects of the strategy ${ }^{22}$. On the other hand, it is pointed out that measures of a financial nature (profit or income) best illustrate level of strategy execu$\operatorname{tion}^{23}$. Particular attention is drawn to the usefulness of ROI as a measure indicating the achievement of the intended benefits of strategic changes introduced ${ }^{24}$. Some researchers

\footnotetext{
${ }^{15} \mathrm{~K}$. Choong, Understanding the features of performance measurement system: a literature review, "Measuring Business Excellence" 17(4)/(2013), p. 114.

${ }^{16}$ P. Perego, F. Hartmann, Aligning Performance Measurement Systems With Strategy: The Case of Environmental Strategy, “Abacus - A Journal of Accounting Finance and Business Studies” 45(4)/(2009), p. $428-432$.

${ }^{17}$ S. Brignall, J. Ballantine, Strategic Enterprise Management Systems: new directions for research, "Management Accounting Research" 15(2004), p. 225.

${ }^{18}$ F. Hoque, Shaping Your Business Strategy, "Baseline" September/(2008), p. 49.

${ }^{19}$ F. Hoque, Turning Ideas Into Action, "Baseline" April/(2008), p. 61.

${ }^{20}$ P. Garengo, S. Biazzo, U. Bititci, Performance measurement system in SMSs: a review for a research agenda, op.cit.

${ }^{21}$ M. Frigo, J. Litman, Strategy, Business Execution, and Performance Measures, "Strategic Finance" $\mathrm{May} /(2002)$, p. 6-8.

${ }^{22}$ M. Frigo, Strategy or Execution?, "Strategic Finance", March/(2003), p. 9.

${ }^{23}$ J. Morgan, Strategy Execution. A Four-Step Process, "American Management Association "MWorld" Winter/(2010-11), p.16.

${ }^{24}$ C. Hanley, The Execution Challenge: Translating Strategy into Action, "Bank Accounting \& Finance" October-November/(2007), p. 19
} 
postulate, however, a greater use of non-financial measures as those more closely connected with the development concept and constituting the basis for a determination of financial goals ${ }^{25}$. By contrast, some research indicates that although companies use nonfinancial measures in operational activities ${ }^{26}$, few of these are formally and directly linked with the strategy and the measurement of its effectiveness ${ }^{27}$. It seems, however, that better results are obtained by monitoring effects of activities conducted with the use of measures related to the nature of the strategy being executed, taking into consideration also the organisational structure and specifics of a given enterprise ${ }^{28}$.

The measurement issue is important in particular in the case of small and mediumsized companies, for which there is a lack of comprehensive models and systems taking into consideration their specifics, which often results in fragmentary implementation of existing solutions. Moreover, modifications (also unintended) are made by the elimination of some elements, which then leads to the execution of systems that are incomplete and unadjusted to the needs characteristic of this group of businesses ${ }^{29}$. In particular small entities are more focused on operational and financial results ${ }^{30}$. This is why their approach to the measurement system is more informal and undetermined and not based on a previously devised schema, but has the nature rather of spontaneous and temporary solutions. It is not, therefore, an effect of a long-term plan and anticipation, which in consequence leads to a lack of coherence between the strategy and its measures ${ }^{31}$. This is particularly significant in the context of a low level of strategy formalisation, by which small organisations are most commonly characterised. A well-thought-out, coherent measurement system could, for this reason, support both a more detailed definition of development concept as well as separation of strategic and operational issues ${ }^{32}$. As some research results indicate, large enterprises conduct more regular measurements and do so more frequently ${ }^{33}$. On the other hand, results obtained are more difficult to interpret ${ }^{34}$.

\footnotetext{
${ }^{25}$ M. Frigo, Nonfinancial Performance Measures and Strategy Execution, "Strategic Finance" August/(2002), p. 6-8.

${ }^{26}$ J. Burns, R. Scapens, S. Turley, The crunch for numbers, “Accountancy” 119(1245)/(1997), p. 86.

${ }^{27}$ C. Gomes, M. Yasin, J. Lisboa, A literature review of manufacturing performance measures and measurement in an organizational context: a framework and direction for future research, "Journal of Manufacturing Technology Management" 15(6)/(2004), p. 522 - 524

${ }^{28}$ F. Fishman, Strategy Execution for Enduring Performance, "Baseline" April/(2009), p. 40.

${ }^{29}$ J. Tenhunen, H. Rantanen, J. Ukko, SME-oriented implementation of a performance Measurement system, Department of Industrial Engineering and Management, Lappeenranta University of Technology, Finland, 2001.

${ }^{30} \mathrm{H}-\mathrm{H}$. Hvolby, A. Thorstenson, Performance Measurement in Small and Medium-Sized Enterprises, "3rd International Conference on Stimulating Manufacturing Excellence in SMEs (Proceedings)", Coventry University, 2000, p. 324-332.

${ }^{31}$ A. Chennell, S. Dransfield, J. Field, N. Fisher, I. Saunders, D. Shaw, OPM: A System for Organisational Performance Measurement, "Performance Measurement - Past, Present and Future (Conference Proceedings)", Cranfield University, Cranfield, 2000, p. 96-103.

${ }^{32}$ M. Hudson, M. Bourne, J. Lean, P. Smart, Only Just Managing - No Time to Measure, "Performance Measurement - Past, Present and Future (Conference Proceedings)", Cranfield University, Cranfield, 2000, p. 243-250.

${ }^{33}$ W. Van Dooren, What Makes Organisations Measure? Hypotheses on the Causes and Conditions for Performance Measurement, "Financial Accountability \& AMP Management" July/(2005), p. 362 - 383.

${ }^{34}$ A. Jääskeläinen, Productivity Measurement and Management in Large Public Service Organizations, Publication 927, Tampere University of Technology, Tampere, 2010
} 
The results of presented research indicate that there are recommendations regarding the characteristics which should represent an effective and comprehensive measurement system. Nonetheless, there is a lack of guidance as to its components. This deficit is of particular significance in the case of strategy implementation and measurement of the effectiveness of this process. It is accepted in this study that strategy implementation measurement should integrate the strategy, the tools for its implementation and measurement frequency ${ }^{35}$ [Kaplan, Norton, 2008]. A comprehensive strategy execution measurement system should therefore take into consideration three areas:

- the use of measurement tools - including typical strategy implementation tools (Balanced Scorecard, budgeting and planning, projects and strategic programs, strategic controlling) (C1);

- the processes - assignment to strategic objectives measures and indicators of their execution, design of an incentive system in which employee remuneration level is dependent on the degree to which strategic objectives are achieved and creation of a system monitoring the environment of the firm $(\mathrm{C} 2)$;

- regularity of the measurement work conducted (C3).

Effectiveness of strategy execution was defined by:

- the level to which intended strategic objectives are achieved - as an indicator showing the efficacy of activities conducted (E1);

- income dynamics - as an indicator showing effects of activities conducted (E2);

- in addition, the organisation size was taken into consideration.

The following research hypothesis was formulated:

- H: There is a positive interdependency between a comprehensive system for the measurement of strategy execution and the effectiveness of this process.

- additional hypotheses were also devised. The first was used to verify whether aspect of the processes in a strategy execution measurement system has an influence on results achieved; H1: Proper design of processes constituting the measurement system affects growth in effectiveness of strategy execution.

- the second, however, was intended to verify the influence of measurement system comprehensiveness on one of the aspects of effectiveness; H2: Design of a comprehensive strategy execution measurement system affects growth in the level of execution of strategic goals assumed.

\section{SAMPLE AND DATA COLLECTION, RESEARCH TOOLS}

The group of respondents included managers of 200 companies that have been operating for at least five years and are listed among the 500 largest polish companies in the ranking of "Polityka" magazine (101 entities) and in the "Forbes Diamonds 2013" ranking (99 companies). The first ranking takes account of sales revenues, the total revenues of the companies, the gross and net profit, as well as the number of staff. The "Diamonds" list included the companies showing the fastest increase in value. The study was conducted the PAPI (Paper and Pencil Interview) technique. In order to ensure the highest possible representativeness, the sample was selected using the stratified random sampling method. The questions in the questionnaire were of nominal value (the respondents declared the

\footnotetext{
${ }^{35}$ R. Kaplan R., D. Norton, The Execution Premium: Linking Strategy to Operations for Competitive Advantage, "Harvard Business Press", Boston, 2008, p. 15.
} 
existence of specific obstacles) and or ordinal variable nature (the respondents indicated the strength of their impact on a 5-point scale). In order to test the hypotheses, Pearson's correlation coefficient was calculated.

\section{RESEARCH RESULTS AND DISCUSSION}

The first stage of the research was calculation of average responses for those areas presented above describing the degree of measurement system comprehensiveness and the degree of effectiveness of strategies executed for each entity surveyed.

Subsequently Pearson's correlation coefficient (level) for the entire examined sample was calculated. The following table 1. indicates the results of the research.

Table 1. Research results. Correlation between the comprehensiveness of the measurement system and the effectiveness of strategy execution

\begin{tabular}{|l|l|}
\hline & Result \\
\hline Pearson correlation &, 469 \\
\hline Dual significance &, 001 \\
\hline $\mathrm{N}$ & 196 \\
\hline
\end{tabular}

Source: Own research.

As the results obtained show, there is an average positive correlation between the comprehensiveness of the measurement of strategy execution and the effectiveness of this process. This means that ensuring the comprehensive functioning of a strategy implementation measurement system, and thus taking into consideration both tools supporting strategy implementation and proper design of implementation processes, as well as determination of the regularity of measurement work, increases the chance of an effective development concept realisation. Although a measurement system is no guarantee that the results desired will be achieved, an organisation which considers in its activities the need for multidimensional design and a complex strategy execution measurement system has a greater chance of the accomplishment of the goals intended, thereby achieving a higher effectiveness of activities performed, expressed in an increase in income dynamics. The main hypothesis can therefore be accepted. In order to accomplish the goal of this work, further research concerned the existence of the correlation described at organisations of different sizes, defined by number of employees. The results are presented table 2 .

Table 2. Correlation between the comprehensiveness of the measurement system and the effectiveness of strategy execution at organisations of different sizes

\begin{tabular}{|l|l|l|l|}
\hline & $\mathbf{0 - 4 9}$ & $\mathbf{5 0 - 2 4 9}$ & $\mathbf{2 5 0 <}$ \\
\hline Pearson correlation &, 172 &, 398 &, 413 \\
\hline Dual significance &, 009 &, 004 &, 012 \\
\hline $\mathrm{N}$ & 68 & 63 & 65 \\
\hline
\end{tabular}

Source: Own research.

As the results obtained present, the level of correlation is lowest in the case of small organisations. This certainly results from a low level of strategy formalization and consequently the least formal system for measurement of its execution and a low regularity of measurement work. The level of correlation for medium-sized and large enterprises is similar and may be defined as medium. No significant differences were observed in the case of these two groups, which differs slightly from the research results mentioned earli- 
er, most of which indicate a higher formality and regularity of measurement work performed at large organisations. In the research discussed, however, no significant differences in level of correlation were indicated, which may mean that executives at both medium-sized and large organisations possess a strategic awareness concerning the need to ensure comprehensiveness in measurement systems designed. Further analysis of results indicated some differences in interdependencies between particular aspects of variables investigated (table 3).

Table 3. Correlations between the elements of measurement system comprehensiveness and the effectiveness of strategy execution

\begin{tabular}{|l|l|l|l|}
\hline & C1 & C2 & C3 \\
\hline Pearson correlation &, 292 &, 456 &, 411 \\
\hline Dual significance &, 015 &, 002 &, 018 \\
\hline $\mathrm{N}$ & 196 & 196 & 196 \\
\hline
\end{tabular}

Source: Own research.

An analysis of the results indicates that the highest level of correlation (0.456) was achieved for the processes constituting the measurement system. This is, therefore, the element affecting most the effectiveness of the strategy executed. The hypothesis H1 may thus be accepted. The lowest level of correlation was average, obtained for the tools used to measure strategy implementation progress. Accordingly, it may be concluded that for the appropriateness and effectiveness of the measurement system it is of key importance to design, in a well-thought-out manner, processes which will provide useful feedback and allow for necessary corrections of observed deviations from the desired level of realisation of particular strategy aspects. Implementation tools play therefore a supporting function and influence the effectiveness of development concept implementation to a lesser degree. It is also important to mention the medium level of correlation for measurement system regularity, which, as research indicates, should be regarded as a significant factor influencing the achievement of the strategic goals intended. Periodicity and regularity of measurement work is a guarantee of the proper functioning of the entire system. Further interdependencies between two elements of strategy execution effectiveness and the measurement system were investigated. The results are presented in the table 4 .

Table 4. Correlation between the elements of the effectiveness of strategy execution and measurement system comprehensiveness.

\begin{tabular}{|l|l|l|}
\hline & E1 & E2 \\
\hline Pearson correlation &, 583 &, 201 \\
\hline Dual significance & 0,022 & 0,11 \\
\hline $\mathrm{N}$ & 196 & 196 \\
\hline
\end{tabular}

Source: Own research.

A considerable difference between the results obtained is visible. The level of assumed strategic goal achievement, as an indicator showing the effectiveness of activities performed, demonstrates a strong, positive correlation with measurement system comprehensiveness. Considering in the measurement system elements belonging to all three specified aspects and their interrelations provides a greater guarantee of assumed goal achievement, and, importantly, their realisation may be regarded as effective. Substantially lower correlation was observed in the case of the second element investigated (E2), which is income 
dynamics. Although this is positive, the result obtained (0.201) should be considered low. Income dynamics as an indicator showing the effects of activities performed is considerably less correlated with a comprehensive measurement system and it is therefore difficult to state unequivocally that its design such affects growth in income achieved. This result is unsurprising as income dynamics are dependent on many variables, including those of an external nature. The results presented allow for acceptance of the $\mathrm{H} 2$ hypothesis.

\section{CONCLUSION}

The issue of strategy execution measurement is a complex and multidimensional problem. On the one hand, it is necessary to consider those measures best adjusted to the specifics of the given organisation which most accurately reflect the level of achievement of the goals assumed. On the other hand, however, it seems essential to take into consideration also other elements which form a measurement system allowing for the effectiveness of activities undertaken to be raised. The research results presented confirm the existence of a relationship between the comprehensiveness of this system and the effectiveness of strategy execution. It has been shown that the greatest role in this regard is played by appropriately designed processes. It should be mentioned also that further analysis of the results obtained proved that individual constituents of the strategy implementation measurement system have a lesser influence on the effectiveness of this process than the combination of them. For this reason it seems imperative to take a holistic perspective and design this system considering the need to achieve the highest possible level of comprehensiveness. It is necessary therefore to ensure the correct functioning of the processes, the use of proper implementation tools and the provision of a defined order and regularity of works performed. Simultaneous collaboration and mutual interaction of the elements mentioned above allow an increase in the effectiveness of strategy execution. It is also worth mentioning that results obtained allow it to be claimed that the comprehensiveness of a measurement system shows a significantly higher correlation with level of strategic goal achievement than with income dynamics.

The main constraint of the research conducted is the declarative nature of some variables, particularly the level of assumed strategic goal achievement. However, it has been recognised as reasonable to use this aspect as a measure connected with the nature of the strategy executed. This is why financial indicators have intentionally not been taken into consideration, since according to the suggestions of some researchers it has been assumed that their analysis does not allow for such precise monitoring of the effects of activities undertaken as the level of strategic goal achievement better reflects the connection with the development concept and the specifics of the given organisation.

\section{ACKNOWLEDGMENTS}

The project was financed from the funds of The National Science Centre, the project number 2014/13/D/HS4/01425 and DEC-2011/03/B/HS4/04247.

\section{REFERENCES}

[1] Brignall S., Ballantine J., Strategic Enterprise Management Systems: new directions for research, Management Accounting Research, 2004, No 15, p. 225.

[2] Burns J., Scapens R., Turley S., The crunch for numbers, Accountancy, 1997, Vol. 119, No. 1245 , pp. 86. 
[3] Chenhall R., Management control system design within its organizational context: findings from contingency-based research and directions for the future, Accounting, Organizations and Society, 2003, Vol. 28, pp. 127-68.

[4] Chennell A., Dransfield S., Field J., Fisher N., Saunders I., Shaw D., OPM: A System for Organisational Performance Measurement, Performance Measurement - Past, Present and Future (Conference Proceedings), Cranfield University, Cranfield, 2000, pp. 96-103.

[5] Choong K., Understanding the features of performance measurement system: a literature review, Measuring Business Excellence, 2013, Vol. 17, No. 4, p. 114.

[6] Dangayach G., Deshmukh S., Manufacturing strategy literature review and some issues, International Journal of Operations \& Production Management, 2001, Vol. 21 No. 7, pp. 884-932.

[7] Fishman F., Strategy Execution for Enduring Performance, Baseline, 2009, April, p. 40.

[8] Forza C., Salvador F., Assessing some distinctive dimensions of performance feedback information in high performing plants, International Journal of Operations and Production Management, 2000, Vol. 20, No. 3, p. 359.

[9] Franco-Santos M., Kennerley M., Micheli P., Martinez V., Mason S., Marr B., Gray D., Neely A., Towards a definition of a business performance measurement system, International Journal of Operations \& Production Management, 2007, Vol. 27, No. 8, p. 795.

[10] Frigo M., Litman J., Strategy, Business Execution, and Performance Measures, Strategic Finance, 2002, May, pp. 6-8.

[11] Frigo M., Nonfinancial Performance Measures and Strategy Execution, Strategic Finance, 2002, August, pp. 6-8.

[12] Frigo M., Strategy or Execution?, Strategic Finance, 2003, March, p. 9.

[13] Garengo P., Biazzo S., Bititci U., Performance measurement system in SMSs: a review for a research agenda, International Journal of Management Reviews, 2005, Vol. 7 No. 1, pp. 25-47.

[14] Gates S., Aligning Strategic Performance Measures and Results, The Conference Board, 1999, New York, p. 4, 24

[15] Gomes C., Yasin M., Lisboa J., A literature review of manufacturing performance measures and measurement in an organizational context: a framework and direction for future research, Journal of Manufacturing Technology Management, 2004, Vol. 15, No. 6, pp. 522 - 524

[16] Hanley C., The Execution Challenge: Translating Strategy into Action, Bank Accounting \& Finance, 2007, October-November, p. 19.

[17] Hoque F., Shaping Your Business Strategy, Baseline, 2008a, September, p. 49.

[18] Hoque F., Turning Ideas Into Action, Baseline, 2008b, April, p. 61.

[19] Hudson M., Bourne M., Lean J., Smart P., Only Just Managing - No Time to Measure, Performance Measurement - Past, Present and Future (Conference Proceedings) Cranfield University, Cranfield, 2000, pp. 243-250.

[20] Hvolby H-H., Thorstenson, A., Performance Measurement in Small and Medium-Sized Enterprises, 3rd International Conference on Stimulating Manufacturing Excellence in SMEs (Proceedings), Coventry University, 2000, pp. 324-332.

[21] Ittner C., Larcker D., Randall T., Performance implications of strategic performance measurement in financial service firms, Accounting, Organizations and Society, 2003, Vol. 28, No. $7 / 8$, p. 734 .

[22] Jääskeläinen A., Productivity Measurement and Management in Large Public Service Organizations, Publication 927, Tampere University of Technology, Tampere, 2010,

[23] Kaplan R., Norton D., The Execution Premium: Linking Strategy to Operations for Competitive Advantage, Harvard Business Press, Boston, 2008, p. 15.

[24] Maisel L., Performance Measurement Practices Survey Results, AICPA, New York, 2001a, p. 12.

[25] Maisel L., Performance Measurement Practices: A Long Way from Strategic Management, Balanced Scorecard Report, 2001b, May - June.

[26] Medori D., Steeple D., A framework for auditing and enhancing performance measurement systems, International Journal of Operations \& Production, 2000, Vol. 20, No. 5, p. 523. 
[27] Morgan J., Strategy Execution. A Four-Step Process, American Management Association, "MWorld" 2010-11, Winter, p.16.

[28] Neely A., Adams C., Kennerley M., The Performance Prism: The Scorecard for Measuring and Managing Stakeholder Relationship, Prentice-Hall, London, 2002.

[29] Perego P., Hartmann F., Aligning Performance Measurement Systems With Strategy: The Case of Environmental Strategy, Abacus - A Journal of Accounting Finance and Business Studies, 2009, Vol. 45, No. 4, pp. $428-432$.

[30] Sirkin H., Keenan P., Jackson A., The hard side of change management, Harvard Business Review, 2005, No. 83(10), pp. 109-118.

[31] Tenhunen J., Rantanen H., Ukko J., SME-oriented implementation of a performance Measurement system, Department of Industrial Engineering and Management, Lappeenranta University of Technology, Finland, 2001.

[32] Van Dooren W., What Makes Organisations Measure? Hypotheses on the Causes and Conditions for Performance Measurement, Financial Accountability \& AMP Management, 2005, July, pp. $362-383$.

\section{KOMPLEKSOWOŚĆ SYSTEMU POMIARU REALIZACJI STRATEGII}

Artykuł opisuje zagadnienie pomiaru realizacji strategii $\mathrm{z}$ uwzględnieniem dwóch zmiennych - poziomu jego kompleksowości oraz efektywności prowadzonych działań. Kompleksowość została zdefiniowana w ramach trzech obszarów: wykorzystania narzędzi służących pomiarowi stopnia realizacji strategii, przebieg procesów oraz pomiar postępów wdrożeniowych. Natomiast efektywność implementacji strategii została wyrażona poprzez poziom realizacji celów strategicznych oraz dynamikę przychodów. Próba badawcza obejmowała 200 przedsiębiorstw działających od minimum 5 lat i wyszczególnionych w rankingu „Polityki” oraz „Diamentów Forbesa 2013”. Wykorzystana została technika PAPI (Paper and Pencil Interview), a pytania miały charakter nominalny (deklarowane było występowanie określonych barier implementacyjnych) oraz zmiennych porządkowych (określano ich oddziaływanie na 5 punktowej skali). W celu weryfikacji postawionych hipotez, obliczona została korelacja Pearsona. Przeprowadzone badania wykazały istnienie dodatniej korelacji pomiędzy nimi, przy czym wskazano, iż największą rolę odgrywają odpowiednio zaprojektowane procesy pomiaru. Jednocześnie istotne jest uwzględnienie wzajemnych interakcji pomiędzy składowymi systemu pomiaru, a więc przyjęcie perspektywy holistycznej i projektowanie go w oparciu o zasadę kompleksowości. Równoległe współdziałanie i wzajemna interakcja wymienionych elementów pozwalają na wzrost efektywności realizacji strategii. Przekłada się to bowiem na osiągane wyniki, zarówno w zakresie dynamiki przychodów, jak i stopnia realizacji celów strategicznych. Warto także wspomnieć, że otrzymane wyniki pozwalają stwierdzić, iż kompleksowość systemu pomiaru wykazuje znacznie większą zależność z poziomem osiągnięcia celów strategicznych, aniżeli z dynamiką przychodów.

Słowa kluczowe: implementacja strategii, system pomiaru, cele strategiczne, zarządzanie strategiczne, kontrola.

\section{DOI: 10.7862/rz.2016.mmr.51}

Tekst złożono w redakcji: październik 2016

Przyjęto do druku: grudzień 2016 